\title{
Chromosome 22
}

National Cancer Institute

\section{Source}

National Cancer Institute. Chromosome 22. NCI Thesaurus. Code C13218.

The designation for each member of the smallest human autosomal chromosome pair. Chromosome 22 spans about 49 million base pairs and represents between 1.5 and 2\% of the total DNA in normal diploid cells. 